\title{
СПЕЦИФІКА ФУНКЦІОНУВАННЯ ОДОРАТИВНОЇ ЛЕКСИКИ У ТВОРАХ М. КОЦЮБИНСЬКОГО
}

Іншакова I. Є. Специфіка функціонування одоративної лексики у творах М. Коцюбинського.

Лексика сприйняття постійно перебуває в колі уваги науковців. У статті розглядається функціонування одоративної лексики в творчості М. Коцюбинського, визначено відповідні тематичні групи лексем із семантикою «запах».

Ключові слова: лексика відчуття, тематичні групи, запах, одоративна лексика.

Иншакова И. Е. Специфика функционирования одоративной лексики в произведениях М. Коцюбинского.

Лексика восприятия постоянно пребывает в центре внимания ученых. В статье рассматривается одоративная лексика в творчестве М. Коцюбинского, определены соответственные тематические группы лексем с семантикой «запах».

Ключевые слова: лексика восприятия, тематические группы, запах, одоративная лексика. works.

Inshakova I. Y. A specific character of functioning of odourative vocabulary in M. Kotsyubynsky's

Vocabulary of perception is constantly attracting researchers' attention. The article deals with the odourative vocabulary in M. Kotsyubynsky's works. The author investigates appropriate thematic groups of lexemes with semantics of «odour».

Key words: vocabulary of perception, thematic groups, odour, odourative vocabulary.

Лексика сприйняття постійно перебуває в колі уваги лінгвістів. У вітчизняному, зарубіжному мовознавстві останні кілька десятиліть підвищений інтерес до феномена запаху й відповідної лексики.

Запахи досліджують у різних аспектах фізіологія, соціологія, культурологія, психологія. В українській, російській лінгвістиці, психолінгвістиці відомі праці, присвячені частковим аспектам опису цієї лексики (I. Я. Франко, О. І. Білецький, В. В. Виноградов, В. П. Сидельников, Л. Вейсгербер, Л. М. Васильєв, Ю. Н. Караулов, А. П. Василевич, Е. В. Гейко, Л. Б. Крюкова, В. В. Лещенко, Н. С. Павлова, І. Г. Рузін, Р. М. Фрумкіна, А. Вежбицька, А. В. Житков, Н. А. Ніколіна, Л. Ставицька, М. В. Одинцова, В. В. Дятчук та ін.).

Запах - конкретна властивість тієї чи тієї реалії, яка в сучасній свідомості віддзеркалюється через нюхове відчуття. Людина сприймає 
безліч запахів. Їх уплив, різноманітність відчуттів відбивається в мові [1, c. 36]. Для передачі відтінків сприймання запаху, його поширення, виділення певним джерелом мова виробила ряд синонімічних засобів. Це іменник-підмет + характерні дієслова типу n'янить, паморочить, душить, лоскоче тощо та дієслова зі значенням «сприймати» + іменник-додаток на позначення запаху взагалі [1, с. 36].

Дієслова (залити, видихати, розливати, пускати тощо) + відповідні іменники, прикметники, на думку В. В. Дятчук, «...дають нові відтінки словесного живописання, надаючи явищам природи властивостей живих організмів, унаслідок чого створюються образні, метафоричні картини» $[1$, c. 42$]$.

Н. С. Павлова, аналізуючи лексику з семою «запах» у мові, мовленні, тексті, виокремлює 15 сем «характеристика запаху». Найбільш частотними вона вважає такі: «оцінка запаху», «інтенсивність запаху», «вплив запаху на людину», «якість запаху» [3, с. 8].

Метою нашої статті $\epsilon$ розгляд специфічної лексико-семантичної групи слів на позначення запаху в творчості М. Коцюбинського.

Засоби передачі запаху у творах письменника різноманітні, активно використовуються дієслова, іменники, прикметники в переносному значенні, синкретичні образи запаху. Кожна частина мови утворює свій семантичний ряд. Наприклад: іменники - запах, задуха, мертвота, нюх, сморід, пахощі, дух, чад, аромат, дим; дієслова - запахла, n'янив, смерділа, курився, війнуло, напоєний, чаділо, несе, полоскотав, тхнуло, шибнуло; прикметники - запашний, смердючий, пахучий, кислий, n'яний, свіжий, спертий, душний, димний, прілий, нудний, солодкий, їдкий, гнилий, задушний, медовий, солодкуватий, гострий; прислівники - душно тощо.

На позначення запахових вражень мова має небагато слів. На цьому наголошував ще І. Я. Франко у праці «Із секретів поетичної творчості»: «Наша мова найбагатша на означення зору, менше багата, але все-таки досить багата на означення вражень слуху і дотику, а найбідніша на означення смаку і запаху» [5, с. 79$]$.

Науковці, аналізуючи семантику синтаксичних конструкцій зі значенням запаху, звертають увагу на явище синкретизму, бо часто перетинаються компоненти смакових, зорових, дотикових відчуттів та ін. Це спостерігаємо і в творчості письменника: Се була оргія квітів і трав, n'яний сон сония, якесь шаленство кольорів, пахощів, форм...(2, с. 34).

Склад лексем із семантикою «запах» представлений словотвірними гніздами 3 одоричною семантикою, узуальними коренями української мови: -пах-, -дух-, -душ-, -чад-, -аромат-, -дим-, -мертв-, -сморід-, -тхн-, -гни-, -мед-, -кур- та ін.

Розглядувані одиниці часто вводяться в текст у конструкціях «дієслово + іменник в О. в.», що називає джерело запаху. Як правило, у ролі таких дієслів виступають слова-специфікатори пахло, дихало, тхнуло, 
війнуло, віддавала та ін.: Засипана глицеюю, щ̧о віддавала прілим духом... (1, с. 408); Скрізь тхнуло гноєм (1, с. 299); Тут було затишно $і$ пахло смолою (1, с. 299); На нього тхнуло теплом із піддашия, а з-під білих ряден почулося сонне сопіння та хропіння (1, с. 238). Більшість таких аналізованих речень є односкладними безособовими.

Характерною рисою творів автора є вживання одоративних лексем у порівняльних зворотах: На нього війнуло, як з гнилого болота улітку, тим знайомим теплом їдальні, молока з чаєм... (2, с. 186); Закопчені стіни, долівка в ямах, а кислий дух поту й розчини, як кіт лінивий на печі, міцно заліг в пекарні (2, с. 131); Ту атмосферу носив Кирило з собою, як квітка запах (2, с. 28); А небо чисте, $і$ темне, $і$ запашне, немов з фіалок (2, с. 11).

Часто використовуються письменником конструкції «іменник + іменник в Р. в.», що вказують на тип, характер, джерело запаху. Це кваліфікатори запаху: 3-під гіллястих кущів дихає на неї тепле повітря, насичене пахощуами чорнозему (1, с. 244); Затуманена запахом квіток... (1, с. 321).

Найбільш частотні слова 3 коренем пах виступають у ролі родового поняття. У текстах із 150 прикладів виявлено 82 словоформи із коренем пах. Це форми іменників: запах, пахощуі; дієслів: запахла; прикметники: запашний, пахучий. Наприклад: Цвіли яблуні; тихе повітря дихало чудовими пахощзами (1, с. 46); Обсипана рожевим світлом, свіжа та гарна, Настя здавалася запашною трояндою (1, с. 84).

Авторський контекст надає лексемам додаткових смислових відтінків (-мед-, -чад-): Над дорогою часом попадалась уся в цзвіту дика груша або кущз черемхи з медовим запахом білих делікатних китиць (1, с. 299); ...Огонь засичав, причаӥвся, дихнув чадом $і$ чорним димом... (1, с. $131) ; . .$. Колосся вже обсмалилось, придиміло, і сніпки лиш чаділи, облиті водою $(1$, с. 131$)$.

У текстах виявлені лексеми, значення кореня яких вказує на конкретний тип запаху (-гор-, -гнил-, -затхл-, -тухл-, -мед-, -пал-, -пріл-, -чад-): Прілий дух гнилих пнів, запах кладовища лісного йшов на них $з$ пущіi... (2, с. 242); Світло коливалось од сміху і чаділо димом (2, с. 248).

Лексеми 3 коренем -нюх- - спеціалізовані, називають соматичні процеси відчуття запаху: Для більшої певності він навіть понюхав корінці, але вони мали звичайний дух (1, с. 212); Уранці дими снувались понад селом і лоскотали ніздрі. Люди нюхали чад і позирали на панський двір (2, с. 139).

Л. Ставицька поділяє запахи на шість груп, що враховують переважно джерела запаху: запахи природи, цивілізації, людські запахи, їжі, напоїв, абстрактні, інші запахи [4, с. 76].

Залежно від джерела запаху можна виокремити в художньому просторі М. Коцюбинського основні тематичні групи слів. Найбільшою за обсягом є група запахів природи, зокрема рослин (близько 25 прикладів). Сам автор переймався цими питаннями: Коли б я хоч трохи переніс на 
папір колорит Гуиульщини $і$ запах Карпат, то йз того був би задоволений (1, с. 29). У творах письменнику безперечно вдалось передати якнайповніше запахи рідної природи. Це аромати степу: Хіба не волею самою віє сей вітер низовий, що зібрав усі пахощі степові... (1, с. 183); полонини: Зеленим духом дихнули смереки, зеленим сміхом засміялися трави... (2, с. 212); Остра полонинська трава сильніше запахла (2, с. 219); Він запускав пальиі в пухнату вовну або з батьківським почуттям брав на руки ягня - i дух полонини віяв тоді над ним та кликав у гори (2, с. 231); запахи трав, сіна: На високих місиях поріс, як джунглі, сивий полин і п'янив повітря гіркими пахощами, густими й задушливими (2, с. 34); Я був наче n'яний од духу дикого полину, щзо залляв скелі $і$ напоїв повітря свойм диханням (2, с. 188); Там вітер віє в міжгір'я, напоєний дроком і полинами, там молодіють кущі, як свіжі дівчата... (2, с. 194); ...Сивий полин і п'янив повітря гіркими пахощами... (2, с. 417); І знов йшли далі по каміниях, що розсипались 3-під підошов, серед килимів дроку, золотого $і$ запашного, над якими чорне ріжкове дерево пускало зелені сльози стручків (2, с. 193); Iз трави йшов запах чебрецю та диктамнусу (1, с. 408); Мене спиняє біла піна гречок, запашна, легка, наче збита крилами бджіл (2, с. 45); Густий запах пізніх гречок і сухої стерні повівся з поля (2, с. 267); Біліє широка бинда гречки, і пахощі повівають (1, с. 502); Сіно таке слизьке, гладеньке, так гарно пахне... (2, с. 134); Вітер шумить поміж стогами, п'яний од духу сіна, хмари лягають в покоси... (2, с. 135); По далеких горбах самотіли тихі гуиульські оседки, вишневі од смерекового диму, яким прокурились, гострі дашки оборогів з запашним сіном... (2, с. 215).

Однією $з$ продуктивних груп одоративів є запахи їжі (близько 17 прикладів): Дух свіжої мамалиги приємно полоскотав йому нюх... (1, с. 234); У млині стояв теплий, приємно солодкуватий запах свіжої кукурудзяної муки (1, с. 340); Подають рибу - $i$ він втягує в себе запашну пару $i$ кладе на тарілку великий шматок $(2$, с. 9$) ;$;бо той чорний разовий хліб, який так гарно, по-сільськи, пахне (2, с. 48); ...Їй так хотілось чогось гарячого, смачного, незвичайного, а запах свіжої линини лоскотав ніздрі, спирав віддих... (2, с. 98); Тепер вже щодня палав у печі веселий вогонь, смачно пахло борщем або галушками... (2, с. 113); Зібралось багато людей, їли капусту, пахло коливо медом... (2, с. 181); Він приносить до стаї запах кулеші та диму $і$ довгим мелодійним тремтінням оповідає...(2, с. 220); ...Викликали часом в нашій уяві напівзабуті картини, запах смачної пари обіду в родинному колі (2, с. 250).

У групі напоїв трапляються запахи чаю, кави, горілки. Наприклад: Горілка сьогодні була гірка, смердюча й не мала сили - не брала (2, с. 23); Він нахиляє лице до мене так, щуо я чую горілчаний дух... (2, с. 60); Мене наповнюють пахощі чаю... (2, с. 62); Дух спирту лоскотав ніздрi, $i$ спазматичним рухом горло ковтало слину (2, с. 160); А коли Савка приніс, він любовно поглянув на пахучий напій ... (2, с. 289); Дух свіжсого чаю 
мішався з озонованим повітрям, в одчинені вікна дивилось зорями небо (1, с. 307); ...A по хаті розходилась запашна пара свіжої кави (1, с. 377); Запах свіжсӧ кави мішавсь із запахом часнику (1, с. 419); Запах горілки, змішавиись з важким духом бакуну, наскрізь прочадив чорні стіни корчми (1, с. 40). Запахи їжі, напоїв та ін. використовує автор в описі побуту, створенні картин життя.

У текстах активно функціонують лексеми як для передачі приємних запахів, так і неприємних: ...Повіяли вітри $і$ принесли на своӥх крилах невідомі досі пахощзі... (1, с. 89); Ллють пахощуі в груди (1, с. 426); Аж пахощи гарні віють від нього (1, с. 479); ...Пахощзі так $і$ обіймають, так $i$ огортають тебе (1, с. 504); Приходив обвіяний духом полів, свіжий, як дика квітка (2, с. 46); Сяду з челяддю обідати, кожне від мене ніс верне смердить. А ти гадаєш - пахне? (2, с. 94); Нi, коли хочеш робити, то роби так, щуоб він не мав охоти вертати, щуоб йому пустка смерділа (2, с. 154); I той нудний запах назавше зв'язався у мене з образом смерті (2, с. 253); ...A люди байдужно вештались серед застарілого запаху трупів... (2, с. 255); Мотря годувала гусей, порожні удень хліви, звідки з глибоких чорних отворів йшов їкий запах (2, с. 285); Вона навіть не типічна $i$ скоріш смердить стоячим багном (2, с. 478); В кутку коло дверей стояв кадіб з капусти; важкий дух гнилої капусти виповняв повітря (1, с. 57); Важкий дух вуглецю розходиться в повітрі, здіймається вгору (1, с. 225); ...Вуглець заб' $\epsilon$ їх їким духом (1, с. 226); Навіть в хату залазить його гострий дух, од якого нудить... (1, с. 379); В кухні сморід (1, с. 501). Часто у творах письменника одоративна лексика супроводжує опис міста: Весь Борислав - одна смердюча яма (2, с. 348); Ще містом смердить (1, с. 502); Чи ж можна мати світлий погляд на життя, живучи в тісним, смердючім місті... (1, с. 505). У семантиці цих слів є наявна пейоративна оцінна сема - негативне ставлення. Серед цієї групи можна виокремити задушні запахи, тютюну: За вікнами билась осіння негода, а в хаті, душній i димній, щзо одна тільки жила серед сонного изарства дитячих ліжок, йшов бій невдоволених душ (2, с. 203); Важкий дух, високі та чорні хати з загратованими вікнами... (1, с. 89); Від заходу насувалася чорна хмара, задушний вітер нахрапом бив об гори, хвилював комиш у плавнях... (1, с. 180); Коли б хоч легенький подих низового вітру приніс на своїх крилах прохолоду, увілляв струмок життя у сю задуху, у сю степову мертвоту (1, с. 183); Заснував хату димок сигари, замережив поміст петлями кроків, наситив повітря думками... (2, с. 287).

Незначною є група лексем для передачі специфічних запахів: Щось чудне, нездорове, химерне, з запахом мускусу... (2, с. 38); Розсипаний иукор хрустів під ногами, мокнув у спирті шафран, гостро лоскочучи ніздрі... (2, с. 252); ...3 жовтим салом, з духом специфічним, кров'ю, покалічене тіло... (2, с. 461); 3 пекарні несеться специфрічний дух свіжої крові й непрохоловшого, от-от ще живого м'яса (2, с. 462); На них війнуло 
холодом та специфічним духом льоху (1, с. 239); Шухляди його стола виповнені були паперами з синіми рядками й наситили хатне повітря специфічним духом (1, с. 389). Мабуть, до специфічних можна було б віднести запахи крові, м'яса: Народ п'янів од запаху крові, хрипіння смерті, порохового диму (2, с. 171); Голі по лікоть руки, вогкі, з запахом свіжого м'яса, слизнули повз мої щоки... (2, с. 251); Коли я тільки дихнув тим солодким теплом свіжого м'яса, перед очима встала у мене смерть бабки (2, с. 253); запах крові (2, с. 461); дух смаленого тіла (2, с. 461).

Із коренем -аромат- виявлений один приклад: Сироко приносить до мене з Африки спеку і аромати Сгипту... (1, с. 30).

Незначна кількість одоративів для передачі косметичних запахів, морських: Чиєсь боа лоскоче щзоки...теплий запах парфум...холодний, гарячий погляд...(2, с. 11); Шелестить літнім шумом нова одежа, пахне запашним милом й шафранним духом свіжої паски (2, с. 256); Він теж з скрипом чобіт присів біля жінки, мало не задихнувшись од солодкого запаху пудри з ї̈ лиця (2, с. 263); До такого пахнув специфічним духом згірклої помади... (1, с. 389); Всі вони дихають сіллю та йодом (2, с. 302); Джузеппе втягає в себе той запах, облизує губи, вічно солоні... (2, с. 302); Пахне канатами, рибою, йодом (2, с. 303).

Виявлені поодинокі приклади інших запахів (абстрактних, землі, поту, явищ, свічок та ін.): Між деревами, в наметах рудого листу, щзось пахло непевно, осінне небо нудьгувало понад бульваром... (2, с. 183); $Я$ забув причинити двері, і звідти тягло бадьорим повітрям, надією на фіалки (2, с. 251); I те «щось» зовсім не пахло щастям, достатком, спокоєм... (1, с. 500); Теплий запах холодного тіла (1, с. 556); запах тепла (1, с. 556); Він упивався весняним повітрям і тими пахощами чорної вогкої землі... (1, с. 121); Вози, худоба і люди збилися в купу, од якої йде пара $i$ пахне потом і лайнаком (2, с. 57); Чорна вода у зрубі, в якій купають блиск свій воскові свічі, щуо пахнуть олійною фарбою... (2, с. 57); Я додаю од себе, щуо сьогодні серед зими пахне весною... (2, с. 297); Коли вітер несе над садами золотистий з ивіту пилок, соние п'янить, наче добре вино... (2, с. 303); Мене затримуе запах пароходного диму (2, с. 308); Стою на дорозі і втягаю у себе той легкий запах (2, с. 308).

Характерною особливістю творів М. Коцюбинського $є$ уживання змішаних, двох і більше кваліфікацій запаху: ...B повітрі бринять мухи, ивірінькають горобиі, пахне свіжою ріллею, травицею, фіалками, пахне весною (1, с. 122); Якісь квітки і зела, невидані перше, тиха ласкавість контурів, запахи трав і землі, теплі, рідні простори (2, с. 283); ...Блідий поломінь лизав сперте повітря, $і$ синій чад, змішавщись з нудним запахом воску та з випаром тіл, висів над глухим гомоном в хаті (2, с. 247); В киплячий казан він сипле муку, крає ї̈ навхрест, і скоро запашна пара мішається з запахом диму (2, с. 227); 3 подри, де сохнуть великі круглі боханиі будзу, повіває на ватага вітер, але не може прогнати зі стаї 
запаху вугля, сиру і овечої вовни. Бо тим самим пахне і ватаг (2, с. 222); ...I вся маса морського повітря, весь запах солі, полинів, сония - проходив крізь нас (2, с. 189); Дух кінського гною і свіжих яблук міцно тримався в повітрі (2, с. 152); Нічна задуха насичена була сильними пахошами татарського зілля, куииру, зогрітої води (1, с. 325).

Навіть у публіцистиці автор уживав образні одоративи: Просто не маєи охоти щзо-небудь послати до «Нової громади»- так звідти несе чимось запліснілим, могильним, так тхне льохом звідти. Потреба в свіжім, європейськім органі дуже відчувається у нас: $\epsilon$ у нас кілька визначних талантів, з'являються нові сили, починає потрохи пахнути весною в нашій літературі...(1, с. 566).

Отже, одоративна лексика в творах М. Коцюбинського відображає особливості особистості письменника, специфічне сприйняття світу автором, служить для повної характеристики пейзажу, персонажа, предмета, явища, $\epsilon$ продуктивним засобом створення художньої образності.

\section{Література}

1. Дятчук В. В. Як передається в мові відчуття запаху / В. В. Дятчук // Культура слова. - К., 1978. Вип. 15. - С. 35-42.

2. Коцюбинський М. М. Твори : у 2-х т. / М. М. Коцюбинський. - К. : Наук. думка, 1988.

3. Павлова Н. С. Лексика с семой «запах» в языке, речи и тексте : автореф. дис. на соискание учён. степени канд. филол. наук : 10.02.01 «Русский язык» / Наталия Сергеевна Павлова. - Екатеринбург, 2006. - 19 с.

4. Ставицька Л. Стать крізь призму запаху / Л. Ставицька // Вісник Львівського ун-ту : Серія філологічна. - 2006. - Вип. 38. - Ч. ІІ. - С. 72-78.

5. Франко І. Я. Із секретів поетичної творчості / Іван Якович Франко // Зібр. творів : у 50-и т. - К., 1980. - T. 37. 